\title{
Effect of phorbol 12,13-dibutyrate on smooth muscle tone in rat stomach fundus
}

\author{
Takayuki MATSUMOTO ${ }^{1}$, Misaki NisHIYAMA ${ }^{1}$, Tsuneo KoBAYASHI ${ }^{1}$, \\ Yutaka KASUYA ${ }^{1}$ and Katsuo KAMATA ${ }^{1}$ \\ ${ }^{1}$ Department of Physiology and Morphology, Institute of Medicinal Chemistry, Hoshi \\ University, Shinagawa-ku, Tokyo 142-8501, Japan
}

\begin{abstract}
We investigated the effects of phorbol 12,13-dibutyrate (PDBu), a typical protein kinase $\mathrm{C}(\mathrm{PKC})$ activator, on smooth muscle tone in the rat stomach fundus. In 5hydroxytriptamine (5-HT)-precontracted stomach fundus strips, PDBu induced dosedependent relaxation, but $4 \alpha$-phorbol 12,13-didecanoate, a phorbol ester that does not activate PKC, did not induce relaxation. A PDBu-induced dose-dependent relaxation was also observed in strips precontracted with platelet-activating factor (PAF), carbachol, or $60 \mathrm{mM} \mathrm{K}^{+}$. In stomach fundus strips pretreated with $\mathrm{PDBu}$, the contractile responses to 5-HT and PAF were completely blocked, but those induced by carbachol and endothelin1 (ET-1) were only partially inhibited. In stomach fundus strips preincubated with carbachol in $\mathrm{Ca}^{2+}$-free medium, the $\mathrm{Ca}^{2+}$-induced contraction was decreased by preincubation with PDBu. In strips preincubated with 5-HT, PAF, or ET-1 in $\mathrm{Ca}^{2+}$-free medium, $\mathrm{Ca}^{2+}$-induced contractions were greatly inhibited by pretreatment with $\mathrm{PDBu}$. These results suggest that in rat stomach fundus strips, PDBu-induced relaxation is mediated by activation of PKC. We speculate that a major factor mediating the relaxant action of $\mathrm{PDBu}$ in rat stomach fundus smooth muscle is represented by a reduction in $\mathrm{Ca}^{2+}$ influx via an inhibition of $\mathrm{Ca}^{2+}$ channels.
\end{abstract}

Key words: contraction, PKC, phorbol ester, relaxation, stomach

\section{Introduction}

Protein kinase $\mathrm{C}(\mathrm{PKC})$ is now known to play an important physiological role in virtually all cell types. Indeed, it appears to be involved in a wide variety of cellular responses, including proliferation, differentiation, desensitization, gene expression, membrane transport, secretion (Goodnight et al., 1994; Ueda et al., 2001; Hofmann, 2004), and smooth muscle contraction (Horowitz et al., 1996; Walsh et al., 1996; Morgan and Leinweber, 1998; Suenaga et al., 2001).

However, conflicting results have been reported as to the effects of PKC on smooth muscle tone. In some, but not all smooth muscles, prolonged exposure to phorbol esters, which are

Correspondence to: Katsuo Kamata, Ph.D., Professor, Department of Physiology and Morphology, Institute of Medicinal Chemistry, Hoshi University, Shinagawa-ku, Tokyo 142-8501, Japan

Phone: +81-3-5498-5856 Fax: +81-3-5498-5856 e-mail: kamata@hoshi.ac.jp 
potent stimulants of PKC (Nishizuka, 1984), induces a slowly developing contraction that takes a few minutes to start and peaks at times often in excess of one hour (Watson and Godfrey, 1988). In addition, phorbol esters potentiate the contractions induced by both high $\mathrm{K}^{+}$(Menkes et al., 1986; Sasaguri and Watson, 1989; Xu et al., 1991; Ahn et al., 1997) and histamine (Holzer and Lippe, 1989). In some instances, the phorbol ester-induced response appears to be dependent on a mobilization of extracellular $\mathrm{Ca}^{2+}$, while in others it appears to be $\mathrm{Ca}^{2+}$ independent. In other smooth muscles, however, such activation of PKC either has no effect on tension or it induces relaxation. For example, phorbol esters reportedly inhibit the contractions induced by histamine (Baraban et al., 1985; Holzer and Lippe, 1989), serotonin (5-HT) (Zhu and Sakai, 1996), carbachol (Menkes et al., 1986; Sasaguri and Watson, 1989) and substance P (Holzer and Lippe, 1989), and these effects are possibly induced by activation of $\mathrm{Na}^{+}-\mathrm{K}^{+}$-ATPase (Sasaguri and Watson, 1990) or via a negative feed-back mechanism (Baraban et al., 1985; Menkes et al., 1986). Moreover, phorbol 12,13-dibutyrate (PDBu) has been found to cause a concentration-dependent decrease in basal tone in the smooth muscle of the internal anal sphincter (Chakder et al., 2001).

To improve our understanding of the role played by PKC in stomach fundus smooth muscle, we examined the effects of PDBu on muscle tension in strips of rat stomach fundus.

\section{Materials and Methods}

\section{Drugs}

The following drugs were used in the present study: atropine sulfate, guanethidine,

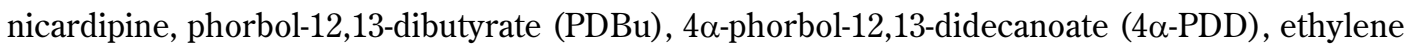
glycol-bis ( $\beta$-aminoethyl ether)-N,N,N',N'-tetraacetic acid (EGTA), 5-hydroxytryptamine creatinine sulfate (5-HT), carbamylcholine chloride (carbachol), and bovine serum albumin (Fraction V) (BSA) (Sigma, St. Louis, MO, U.S.A); endothelin-1 (ET-1) (Peptide Institute Inc., Osaka, Japan); and 1-0-alkyl-2-acetyl-sn-glyceryl-3-phosphorylcholine (PAF) (Bachem, Switzerland). All drugs were dissolved in saline, except PDBu and $4 \alpha-\mathrm{PDD}$, which were dissolved in DMSO; control experiments confirmed the absence of significant effects on smooth muscle tone at the final vehicle concentration used. All concentrations are expressed as the final molar concentration of the base in the organ bath. When responses to PAF were to be examined, $0.25 \%$ BSA was added to the modified Krebs Ringer solution (KRS), because PAF was found to adhere to plastic and to glassware.

\section{Preparation of tissues and experimental protocol}

Male Wistar rats were anesthetized with sodium pentobarbital (50 mg/kg, i.p.), then killed by decapitation. The stomach was excised, and stomach fundus strip preparations approximately $20 \mathrm{~mm}$ in length and $2 \mathrm{~mm}$ in width were made essentially by our previously published methods (Kamata et al., 1988, 1993a, b, c). Each strip was cut out along the longitudinal muscle, and the mucous layer was completely removed to avoid reflex activity. The fundus strips were suspended in a $10 \mathrm{ml}$ organ bath containing modified $\mathrm{KRS}$ at $37^{\circ} \mathrm{C}$, aerated with $95 \% \mathrm{O}_{2}$ and $5 \% \mathrm{CO}_{2}$. The tension loaded on each strip was $1.0 \mathrm{~g}$. Contractions were 
recorded isotonically using an isotonic transducer connected to an ink-writing recorder (Nihon Kohden, Tokyo, Japan). The composition of the modified KRS was as follows (in $\mathrm{mM}$ ): $\mathrm{NaCl}$ 120; $\mathrm{KCl}$ 4.7; $\mathrm{CaCl}_{2}$ 2.0; $\mathrm{MgCl}_{2}$ 1.2; $\mathrm{NaHCO}_{3} 25 ; \mathrm{KH}_{2} \mathrm{PO}_{4}$ 1.2; and glucose 14. Each strip was placed in an organ bath containing KRS, equilibrated with $95 \% \mathrm{O}_{2}$ and $5 \% \mathrm{CO}_{2}$, and left for 30 min at $37^{\circ} \mathrm{C}$. When drugs were applied to the strip, it was preincubated with $10^{-6} \mathrm{M}$ atropine and $10^{-6}$ $\mathrm{M}$ guanethidine (to avoid cholinergic and adrenergic effects being induced throughout the experiment). To allow relaxation responses to be observed, strips were precontracted with 5-HT $\left(10^{-6} \mathrm{M}\right)$, PAF $\left(10^{-7} \mathrm{M}\right)$, carbachol $\left(10^{-6} \mathrm{M}\right)$, or $60 \mathrm{mM} \mathrm{K} \mathrm{K}^{+}$. When a given drug-induced contraction had reached a plateau level, PDBu $\left(10^{-10}-10^{-6} \mathrm{M}\right)$ or $4 \alpha$-PDD $\left(10^{-10}-10^{-6} \mathrm{M}\right)$ was added in a cumulative manner. To examine the effects of PDBu on a given drug-induced contraction, strips were exposed to $\mathrm{PDBu}$ for $20 \mathrm{~min}$, and then the test drug was added in a cumulative manner, with the PDBu remaining present thereafter. When $\mathrm{Ca}^{2+}$-induced contractions in the presence or absence of agonists were to be examined, strips were first exposed to a nominally $\mathrm{Ca}^{2+}$-free KRS containing $0.01 \mathrm{mM}$ EGTA. Then, $\mathrm{Ca}^{2+}\left(10^{-6}-3 \times 10^{-3} \mathrm{M}\right)$ was cumulatively applied to the depolarized fundus while it was bathed in $\mathrm{Ca}^{2+}$-free $\mathrm{KRS}$.

\section{Statistical analysis}

The contractile force developed by stomach fundus strips is expressed in $\mathrm{g}$ tension $/ \mathrm{mg}$ tissue, the data being given as the mean \pm S.E.M. When appropriate, statistical differences were assessed using Dunnett's test for multiple comparisons after a one-way analysis of variance, a probability level of $P<0.05$ being regarded as significant.

\section{Results}

Effect of PDBu on 5-HT-induced smooth muscle tone in stomach fundus strips

As shown in Fig. 1, when 5-HT $\left(10^{-6} \mathrm{M}\right)$ was applied to stomach fundus strips, a contractile response was observed. This 5 -HT-induced contraction was greatly inhibited by pretreatment with $\mathrm{PDBu}\left(10^{-6} \mathrm{M}\right)$ (Fig. 1, upper panel). If, on the other hand, PDBu was applied when the contraction induced by 5 -HT $\left(10^{-6} \mathrm{M}\right)$ had reached a plateau, PDBu $\left(10^{-6} \mathrm{M}\right)$ induced a relaxation (Fig. 1, lower panel), and the PDBu-induced relaxation was dose-dependent (Fig. 2A). In contrast, an inactive phorbol ester ( $4 \alpha-\mathrm{PDD})$ did not induce relaxation (Fig. 2A).

\section{Relaxation responses induced by $P D B u$ in stomach fundus strips}

When the contraction induced by PAF $\left(10^{-7} \mathrm{M}\right)$, carbachol $\left(10^{-6} \mathrm{M}\right)$, or high $\mathrm{K}^{+}(60 \mathrm{mM})$ had reached a plateau, PDBu $\left(10^{-10}-10^{-6} \mathrm{M}\right)$ was added cumulatively (Fig. 2B). At certain concentration, $\mathrm{PDBu}$ induced relaxation on all these drug-induced contractions as it had on that induced by 5 -HT.

\section{Effect of PDBu on various drug-induced contractions}

To determine whether any agonist-induced contractile responses in the stomach fundus might be altered in strips pretreated with $\mathrm{PDBu}$, we examined several agonist-induced contractions in the presence of PDBu $\left(10^{-6} \mathrm{M}\right)$ (Fig. 3). The 5-HT $\left(10^{-10}-10^{-6} \mathrm{M}\right)$ - and PAF 

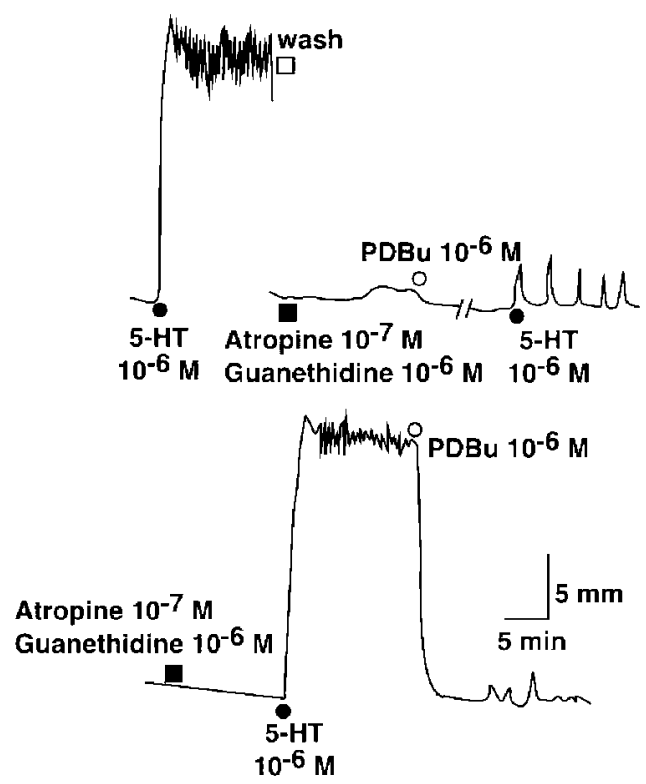

Fig. 1. Effect of PDBu $\left(10^{-6} \mathrm{M}\right)$ on 5-HT-induced contractile response in rat stomach fundus. Upper panel shows pretreatment effect of PDBu. Lower panel shows post-treatment effect of PDBu.

A

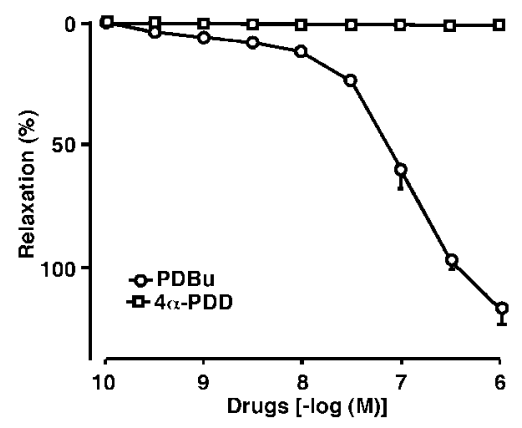

B

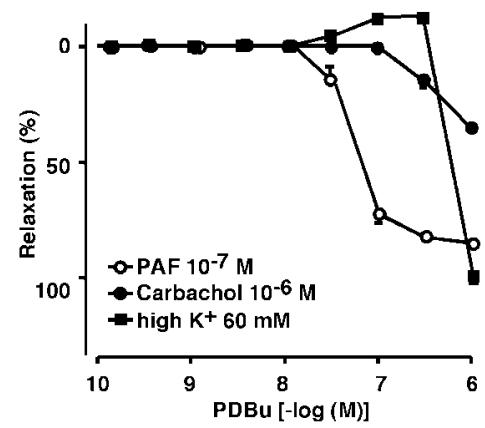

Fig. 2. Concentration-response curves for relaxation responses to PDBu and 4 $\alpha$-PDD in rat stomach fundus precontracted (A) with 5-HT $\left(10^{-6} \mathrm{M}\right)$ and $(B)$ with PAF $\left(10^{-7} \mathrm{M}\right)$, carbachol $\left(10^{-6} \mathrm{M}\right)$, or high potassium $(60 \mathrm{mM})$. Each value represents mean with S.E.M. for 4-6 experiments, the SE mean being included only when it exceeds the dimension of the symbol used.

$\left(10^{-10}-10^{-6} \mathrm{M}\right)$-induced dose-dependent contractile responses were completely blocked by PDBu pretreatment (Fig. 3, A, B). The carbachol $\left(10^{-9}-10^{-5} \mathrm{M}\right)$-induced contraction showed a significant right-ward shift in the presence of $\mathrm{PDBu}\left(10^{-6} \mathrm{M}\right)$, but it was unaffected by the presence of $4 \alpha$-PDD $\left(10^{-6} \mathrm{M}\right)$ (Fig. $\left.3 \mathrm{C}\right)$. The ET-1 $\left(10^{-10}-10^{-7} \mathrm{M}\right)$-induced contraction was significantly reduced in the presence of $\mathrm{PDBu}\left(10^{-6} \mathrm{M}\right)$ (Fig. 3D). Isotonic high $\mathrm{K}^{+}(10-60 \mathrm{mM})$ induced a concentration-dependent rise in tension, and this tended (non-significantly) to be 

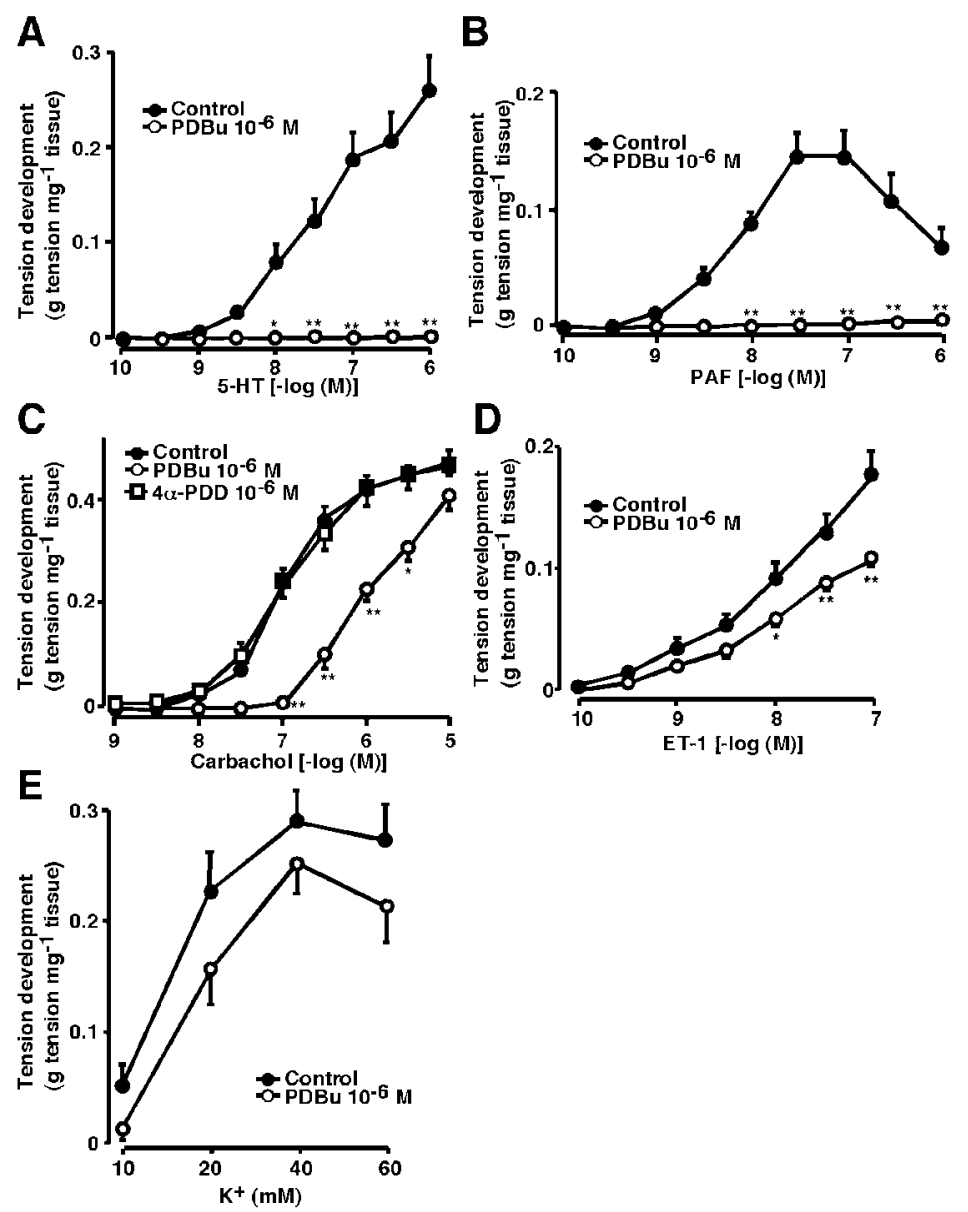

Fig. 3. Concentration-response curves for contractile responses of rat stomach fundus to (A) 5-HT, (B) PAF, (C) carbachol, (D) ET-1, and (E) potassium in the absence (closed symbol) and presence (open symbol) of PDBu $\left(10^{-6} \mathrm{M}\right)$ or $4 \alpha-\mathrm{PDD}\left(10^{-6} \mathrm{M}\right)$. Each value represents mean with S.E.M. for 6 or 7 experiments, the SE mean being included only when it exceeds the dimension of the symbol used. *, $P<0.05$, **, $P<0.01$ vs. control.

decreased in the presence of PDBu $\left(10^{-6} \mathrm{M}\right)$ (Fig. 3E).

\section{Effects of $\mathrm{PDBu}$ on $\mathrm{Ca}^{2+}$-induced contraction}

As shown in Fig. $4 \mathrm{~A}, \mathrm{Ca}^{2+}\left(\mathrm{CaCl}_{2}\right)$ induced a concentration-dependent contraction in stomach fundus strips bathed in an initially $\mathrm{Ca}^{2+}$-free solution, and this contraction was completely suppressed by treatment with $10^{-6} \mathrm{M} \mathrm{PDBu}$. Preincubation with 5-HT did not significantly alter these $\mathrm{Ca}^{2+}$-induced contractile responses in the absence of PDBu (Fig. 4A). $\mathrm{Ca}^{2+}$-induced contractile response in the presence of 5-HT was also completely blocked by treatment with PDBu (Fig. 4A). As reported previously (Kamata et al., 1993a), PAF (10-7 M) augmented the contraction induced by $\mathrm{Ca}^{2+}$ in $\mathrm{Ca}^{2+}$-free solution, and this augmentation was completely blocked by $10^{-6} \mathrm{M} \mathrm{PDBu}$ (Fig. 4B). A similar result was observed when ET-1 was given as pretreatment 
A

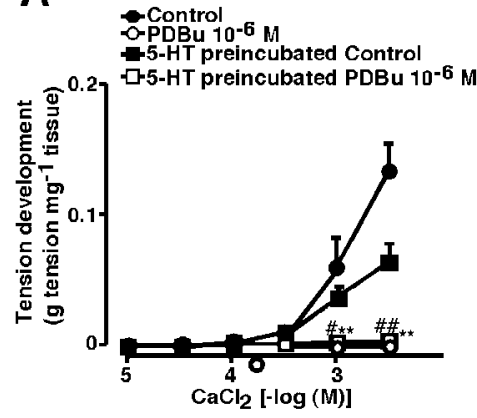

C Preincubated with carbachol (10-6 M)

- Control

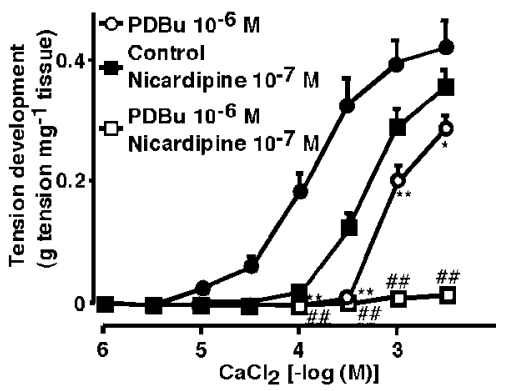

B Preincubated with PAF $\left(10^{-7} \mathrm{M}\right)$

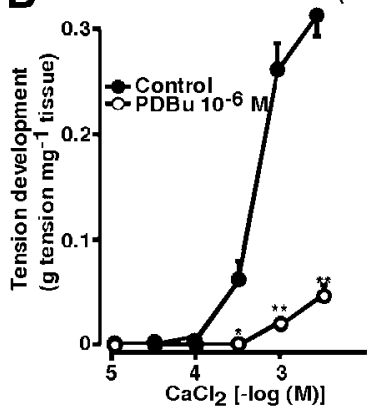

D Preincubated with ET-1 (10-7 M)

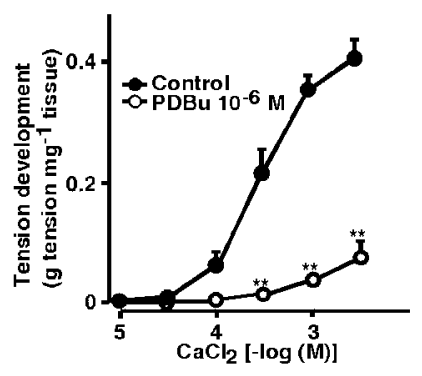

Fig. 4. Concentration-response curves for contractile responses of rat stomach fundus to $\mathrm{CaCl}_{2}$ in the absence (closed symbol) and presence (open symbol) of PDBu $\left(10^{-6} \mathrm{M}\right)$. Tissue were preincubated in $\mathrm{Ca}^{2+}$-free medium with (A) 5-HT $\left(10^{-6} \mathrm{M}\right)$, (B) PAF $\left(10^{-7}\right.$ $\mathrm{M})$, (C) carbachol $\left(10^{-6} \mathrm{M}\right)$, or (D) ET-1 $\left(10^{-7} \mathrm{M}\right)$. Each value represents mean with S.E.M. for 6 or 8 experiments, the SE mean being included only when it exceeds the dimension of the symbol used. *, $P<0.05$, **, $P<0.01$ vs. control. \#, $P<0.05,{ }^{\# \#}, P<0.01$ vs. 5-HT-preincubated control (A) or nicardipine-preincubated control (C).

instead of PAF (Fig. 4D). Carbachol $\left(10^{-6} \mathrm{M}\right)$ augmented the contraction induced by $\mathrm{Ca}^{2+}$ in $\mathrm{Ca}^{2+}$-free solution, and this augmentation was partly antagonized by $10^{-7} \mathrm{M}$ nicardipine, a selective L-type $\mathrm{Ca}^{2+}$ channel inhibitor, and $10^{-6} \mathrm{M} \mathrm{PDBu}$ (Fig. 4C). A combination of nicardipine and $\mathrm{PDBu}$ (same concentrations as above) almost completely suppressed the contraction induced by $\mathrm{Ca}^{2+}$ in $\mathrm{Ca}^{2+}$-free solution.

\section{Discussion}

The main observations made in the present study were that in rat stomach fundus longitudinal smooth muscle, the $\mathrm{PKC}$ activator $\mathrm{PDBu}$ induced a relaxation response, and also attenuated the contractile responses induced by various agonists and by $\mathrm{Ca}^{2+}$.

The effect of PKC on smooth muscle tone is controversial, with results depending on the species, the type of smooth muscle, and the membrane receptor agonist studied (See Introduction). In the present study, when rat stomach fundus strips were precontracted with any of a number of agonists (5-HT, PAF, carbachol, and isotonic high $\mathrm{K}^{+}$solution), PDBuinduced a dose-dependent relaxation (Figs. 1, 2). The maximal PDBu-induced relaxation was 
weaker in strips precontracted with carbachol than in those precontracted with either 5-HT or PAF (Fig. 2). These results suggest that the magnitude of the PDBu-induced relaxant effect in this tissue depends on the nature of the drug used to produce the precontraction. To extend our investigation of the effect of $\mathrm{PDBu}$ on smooth muscle tone, we therefore examined the contractions induced by various agonists in the presence of $\mathrm{PDBu}$.

Smooth muscle contractile responses are the final result of an influx of extracellular calcium and/or a mobilization of intracellular calcium. Several types of $\mathrm{Ca}^{2+}$-channels, such as voltageoperated $\mathrm{Ca}^{2+}$-channels (VOCCs) and receptor-operated $\mathrm{Ca}^{2+}$-channels (ROCCs), are activated when agonists act on a range of G-protein-coupled receptors, whereas store-operated calcium channels (SOCCs) are activated by depletion of the calcium stores within the sarcoplasmic reticulum (Meisheri et al., 1981; Karaki and Weiss, 1984; McFadzean and Gibson, 2002). Reportedly, 5-HT and PAF have no significant effects on phosphatidyliositol (PI) turnover in the rat stomach fundus (Secrest et al., 1989; Kamata et al., 1993b). Indeed, these reagents primarily utilize extracellular calcium to contract this tissue (Secrest et al., 1989; Kamata et al., 1993a). On the other hand, in a variety of smooth muscles carbachol and ET-1 increase PI turnover (Yang et al., 1994; Prestwich and Bolton, 1995) and activate $\mathrm{Ca}^{2+}$-channels (Kawanabe et al., 2002; So and Kim, 2003). In the present study, the 5-HT- and PAF-induced contractile responses were completely blocked in the presence of PDBu (Fig. 1, Fig. 3A, 3B). This suppressive effect of $\mathrm{PDBu}$ on the 5-HT-induced contraction in rat stomach fundus is consistent with a previous finding (Zhu and Sakai, 1996). On the other hand, the carbachol- and ET-1-induced contractions were only partially inhibited by $\mathrm{PDBu}$ (Fig. 3C, 3D). High $\mathrm{KCl}$ is known to cause membrane depolarization and hence to stimulate $\mathrm{Ca}^{2+}$ entry through VOCC (Khalil and van Breeman, 1995). In our study, the isotonic $\mathrm{K}^{+}$-induced contraction tended to be decreased in the presence of $\mathrm{PDBu}$ (Fig. 3E). Moreover, $\mathrm{Ca}^{2+}$ is able to cause contraction of rat stomach when added to an initially $\mathrm{Ca}^{2+}$-free bathing solution (Kamata et al., 1993a). Since such a $\mathrm{Ca}^{2+}$-induced contraction in $\mathrm{Ca}^{2+}$-free solution is completely abolished by treatment with the calcium antagonist nicardipine (Kamata et al., 1993a), it is likely that VOCC activity in the fundus is increased in $\mathrm{Ca}^{2+}$-free solution. In the present study, PAF, but not 5 -HT, augmented the $\mathrm{Ca}^{2+}$-induced contraction observed in $\mathrm{Ca}^{2+}$-free solution (Fig. 4A, 4B), and the contractions induced by these two reagents were completely abolished by PDBu. Furthermore, the carbachol-induced augmentation of the $\mathrm{Ca}^{2+}$-induced contraction was significantly weaker in the presence of $\mathrm{PDBu}$, and the residual contraction was completely abolished by additional treatment with nicardipine (Fig. 4C). Further, ET-1 augmented the $\mathrm{Ca}^{2+}$-induced contraction seen in $\mathrm{Ca}^{2+}$-free solution (Fig. 4D), and the ET-1-induced augmentantion of this contraction was completely abolished by PDBu. These results suggest (a) that PAF, carbachol, and ET-1 depolarize the stomach fundus and hence open VOCC, thereby causing contraction via an influx of extracellular $\mathrm{Ca}^{2+}$ through the open VOCC, and (b) that PDBu inhibits this pathway. Taken together, the above findings lead us to conclude that the suppressive effects of PDBu on stomach fundus smooth muscle tone are due to reduced $\mathrm{Ca}^{2+}$-channel activity, rather than to reduced PI turnover. Although we did not investigate the effects of $\mathrm{PDBu}$ on $\mathrm{Ca}^{2+}$ movement or electrophysiological $\mathrm{Ca}^{2+}$ current, this speculation is supported by the finding that addition of PDBu to intact canine gastric smooth muscles reduced $\mathrm{Ca}^{2+}$ transients and contractions (Ozaki et al., 1993). 
The precise relationship between $\mathrm{PKC}$ activation and the PDBu-induced relaxation of rat stomach fundus smooth muscle remains unknown. Data from several reports suggest that the inhibition of agonist-induced contraction by phorbol esters may occur via a direct inhibition of inositol phosphates or via an activation of $\mathrm{Na}^{+}-\mathrm{K}^{+}$-ATPase, resulting in a membrane hyperpolarization and inhibition of VOCC (Holzer and Lippe, 1989; Sasaguri and Watson, 1990; Mitsui and Karaki, 1993). However, a direct inhibition of $\mathrm{Ca}^{2+}$ channels (VOCC, ROCC) by phorbol esters has also been reported (Prestwich and Bolton, 1995; Sena et al., 1995; Korchak et $a l ., 2001)$. The results obtained in the present study implicate a reduced $\mathrm{Ca}^{2+}$ influx via an inhibition of $\mathrm{Ca}^{2+}$ channels as a potential underlying mechanism for negative regulation by $\mathrm{PKC}$ and the consequent induction of relaxation, at least in the smooth muscle of the rat stomach fundus. Further investigations will be necessary, however, to confirm or deny this idea.

\section{Acknowledgements}

This study was supported in part by the Ministry of Education, Culture, Sports, Science and Technology, Japan, and by the Promotion and Mutual Aid Cooperation for Private Schools of Japan.

\section{References}

Ahn, S.C., Kim, Y.C., Kim, S.J., So, I. and Kim, K.W. (1997). Dual roles of phorbol 12,13-dibutyrate in the regulation of guinea-pig gastric contraction. J. Smooth Muscle Res. 33: 11-22.

Baraban, J.M., Gould, R.J., Peroutka, S.J. and Snyder, S.H. (1985). Phorbol ester effects on neurotransmission: interaction with neurotransmitters and calcium in smooth muscle. Proc. Natl. Acad. Sci. U.S.A. 82: 604-607.

Chakder, S., Sarma, D.N. and Rattan, S. (2001). Mechanism of internal anal sphincter smooth muscle relaxation by phorbol 12,13-dibutyrate. Am. J. Physiol. Gastrointest. Liver Physiol. 280: G1341G1350.

Goodnight, J., Mischak, H. and Mushinski, J.F. (1994). Selective involvement of protein kinase C isozymes in differentiation and neoplastic transformation. Adv. Cancer Res. 64: 159-209.

Hofmann, J. (2004). Protein kinase C isozymes as potential targets for anticancer therapy. Curr. Cancer Drug Targets. 4: 125-146.

Holzer, P. and Lippe, I.T. (1989). Protein kinase C may regulate the tonic component of intestinal smooth muscle contraction in response to substance P. Naunyn-Schmiedebergs Arch. Pharmacol. 339: 214-220.

Horowitz, A., Menice, C.B., Laporte, R. and Morgan, K.G. (1996). Mechanisms of smooth muscle contraction. Physiol. Rev. 76: 967-1003.

Kamata, K., Arai, Y. and Kasuya, Y. (1993a). Mechanism of the contractile response to platelet-activating factor (PAF) of the rat stomach fundus. I. PAF-induced contractile response and calcium mobilization. Gen. Pharmacol. 24: 1331-1336.

Kamata, K., Arai, Y. and Kasuya, Y. (1993b). Mechanism of the contractile response to platelet-activating factor (PAF) of the rat stomach fundus. II. PAF-induced phosphatidylinositol turnover and desensitization. Gen. Pharmacol. 24: 1337-1341.

Kamata, K., Kohzuki, M., Misawa, M. and Kasuya, Y. (1993c). Involvement of nitric oxide pathway in non-adrenergic non-cholinergic (NANC) relaxation in the rat stomach: differential innervation of NANC nerves in the longitudinal and circular muscle of the fundus. Gen. Pharmacol. 24: 
1403-1410.

Kamata, K., Sakamoto, A. and Kasuya, Y. (1988). Similarities between the relaxations induced by vasoactive intestinal peptide and by stimulation of the non-adrenergic non-cholinergic neurons in the rat stomach. Naunyn-Schmiedeberg's. Arch. Pharmacol. 338: 401-406.

Karaki, H. and Weiss, G.B. (1984). Calcium channels in smooth muscle. Gastroenterol. 87: 960-970.

Kawanabe, Y., Hashimoto, N. and Masaki, T. (2002). Characterization of $\mathrm{Ca}^{2+}$ channels involved in endothelin-1-induced contraction of rabbit basilar artery. J. Cardiovasc. Pharmacol. 40: 438-447.

Khalil, R.A. and van Breemen, C. (1995). Mechanisms of calcium mobilization and homeostasis in vascular smooth muscle and their relevance to hypertension. In: Hypertension: pathophysiology, diagnosis and management, ed. by J.H. Laragh and B.M. Brenner, Raven Press, New York, pp. 523-540.

Korchak, H.M., Corkey, B.E., Yaney, G.C. and Kilpatrick, L.E. (2001). Negative regulation of ligandinitiated $\mathrm{Ca}^{2+}$ uptake by PKC- $\beta$ II in differentiated HL60 cells. Am. J. Physiol. Cell Physiol. 281: C514-C523.

McFadzean, I. and Gibson, A. (2002). The developing relationship between receptor-operated and storeoperated calcium channels in smooth muscle. Br. J. Pharmacol. 135: 1-13.

Meisheri, K.D., Hwang, O. and Van Breemen, C. (1981). Evidence for two separate $\mathrm{Ca}^{2+}$ pathways in smooth muscle plasmalemma. J. Membr. Biol. 59: 19-25.

Menkes, H., Baraban, J.M. and Snyder, S.H. (1986). Protein kinase C regulates smooth muscle tension in guinea-pig trachea and ileum. Eur. J. Pharmacol. 122: 19-27.

Mitsui, M. and Karaki, H. (1993). Contractile and relaxant effects of phorbol ester in the intestinal smooth muscle of guinea-pig taenia caeci. Br. J. Pharmacol. 109: 229-233.

Morgan, K.G. and Leinweber, B.D. (1998). PKC-dependent signalling mechanisms in differentiated smooth muscle. Acta. Physiol. Scand. 164: 495-505.

Nishizuka, Y. (1984). The role of protein kinase C in cell surface signal transduction and tumor promotion. Nature 308: 693-698.

Ozaki, H., Gerthoffer, W.T., Hori, M., Karaki, H., Sanders, K.M. and Publicover, N.G. (1993). Ca ${ }^{2+}$ regulation of the contractile apparatus in canine gastric smooth muscle. J. Physiol. 460: 33-50.

Prestwich, S.A. and Bolton, T.B. (1995). Inhibition of muscarinic receptor-induced inositol phospholipid hydrolysis by caffeine, $\beta$-adrenoceptors and protein kinase $\mathrm{C}$ in intestinal smooth muscle. $\mathrm{Br}$. $J$. Pharmacol. 114: 602-611.

Sasaguri, T. and Watson, S.P. (1989). Protein kinase C regulates the tonic but not the phasic component of contraction in guinea-pig ileum. Br. J. Pharmacol. 98: 791-798.

Sasaguri, T. and Watson, S.P. (1990). Phorbol esters inhibit smooth muscle contractions through activation of $\mathrm{Na}^{+}-\mathrm{K}^{+}-\mathrm{ATPase}$. Br. J. Pharmacol. 99: 237-242.

Secrest, R.J., Schoepp, D.D. and Cohen, M.L. (1989). Comparison of contractions to serotonin, carbamylcholine and prostaglandin $\mathrm{F}_{2 \alpha}$ in rat stomach fundus. J. Pharmacol. Exp. Ther. 250: 971-978.

Sena, C.M., Tome, A.R., Santos, R.M. and Rosario, L.M. (1995). Protein kinase C activator inhibits voltage-sensitive $\mathrm{Ca}^{2+}$ channels and catecholamine secretion in adrenal chromaffin cells. FEBS. Lett. 359: 137-141.

So, I. and Kim, K.W. (2003). Nonselective cation channels activated by the stimulation of muscarinic receptors in mammalian gastric smooth muscle. J. Smooth Muscle Res. 39: 231-247.

Suenaga, H., Kasuya, Y. and Kamata, K. (2001). Effects of calmodulin antagonist (W-7) on phorbol ester (PMA)-induced contractile response in isolated rat aorta. J. Smooth Muscle Res. 37: 1-7.

Ueda, H., Inoue, M. and Matsumoto, T. (2001). Protein kinase C-mediated inhibition of mu-opioid receptor internalization and its involvement in the development of acute tolerance to peripheral mu-agonist analgesia. J. Neurosci. 21: 2967-2973.

Walsh, M.P., Horowitz, A., Clement-Chomienne, O., Andrea, J.E., Allen, B.G. and Morgan, K.G. (1996). 
Protein kinase $\mathrm{C}$ mediation of $\mathrm{Ca}^{2+}$-independent contractions of vascular smooth muscle. Biochem. Cell Biol. 74: 485-502.

Watson, S.P. and Godfrey, P.P. (1988). The role of receptor-stimulated inositol phospholipid hydrolysis in the autonomic nervous system. Pharmacol. Ther. 38: 387-417.

Xu, S., Collins, M.A. and Chang, K.J. (1991). Phorbol esters induce oscillatory contractions of intestinal smooth muscles. Eur. J. Pharmacol. 201: 215-222.

Yang, C.M., Yo, Y.L., Ong, R. and Hsieh, J.T. (1994). Endothelin- and sarafotoxin-induced phosphoinositide hydrolysis in cultured canine tracheal smooth muscle cells. J. Neurochem. 62: 1440-1448.

Zhu, B.H. and Sakai, Y. (1996). Alteration of contractile properties to serotonin in gastric fundus smooth muscle isolated from streptozotocin (STZ)-induced diabetic rats. J. Smooth Muscle Res. 32: 165173.

(Received December 9, 2004; Accepted March 5, 2005) 